INTERMARUM: history, policy, culture. - Issue 8 .

UDC 94:329.733(477.82)"1939-1945"

DOI $10.35433 /$ history. 11206

Stepanchuk Olga,

Postgraduate Student at the Department of History of Ukraine, Zhytomyr Ivan Franko State University notabene0606@gmail.com

\title{
ACTIVITIES OF OLEH SHTUL-ZHDANOVYCH DURING WORLD WAR II
}

\begin{abstract}
The aim of the article is to study the political, social and cultural activities of Oleh Shtul-Zhdanovych during World War II. In the process of the research general and special historical methods and basic principles of historical knowledge were used. The principles of historicism and scientificity allowed to analyze the activities of Oleh Shtul-Zhdanovych seen in the perspective of social and political events of the time. The principle of objectivity helped to critically analyze the literature and source base of the study. The principle of systematicity allowed to form a holistic picture of the activities of Oleh Shtul-Zhdanovych during World War II. Being based on the available source base, the article presents an unprecedented generalized image of Oleh Shtul-Zhdanovych's activity during World War II, comprising the scientific novelty of the research. The author made conclusions that the political activity of Oleh Shtul-Zhdanovych during World War II was quite active and diverse. He became a member of the OUN (M) marching groups and actively participated in the political life of occupied Kyiv, closely cooperating with leading figures of the nationalist movement, especially with Olena Teliha and Oleh Olzhych.

Oleh Shtul-Zhdanovych's social and cultural activity during World War II is represented by his work in the editorial office of the newspaper "Ukrainske Slovo" ("Ukrainian Word") (Kyiv). Oleh Shtul-Zhdanovych's cooperation with Taras Bulba-Borovets was of great importance, while its purpose was to unite all independent forces against a common enemy. In fact, their cooperation supported a permanent political connection between the OUN (M) and the forces of Taras Bulba-Borovets. According to Oleh Shtul-Zhdanovych, the main goal of any struggle was to gain Ukraine's independence. In general, the research provides an estimation of the political, social and cultural activities of Oleh Shtul-Zhdanovych in the Ukrainian lands during World War II.
\end{abstract}


IНТЕРМАРУМ: історія, політика, культура. - Вип. 8.

Key words: Oleh Shtul-Zhdanovych, World War II, the OUN (M), the newspaper "Ukrainske Slovo" ("Ukrainian Word"), political activity.

Introduction. An important trend in modern historical research is studying the events of World War II in the Ukrainian lands, including the period of occupation. Emphasis is also placed on the activities of Ukrainian national organizations, aimed at reviving the state independence of Ukraine. In this context, a significant role was played by the representative of the OUN (M) (Organization of Ukrainian Nationalists under the leadership of Andrii Melnyk) Oleh ShtulZhdanovych, whose activities during World War II (political, social, cultural) were quite intense. Hence, a thorough study is to be conducted on the issue.

For now modern historiography has no complex study of the activities of O. Shtul-Zhdanovych during World War II. Researchers, including Bohdan Zek, turned to the person of Shtul-Zhdanovych prevalently in the framework of studying certain areas of his activity in general (Zek, 2013). The activity of O. Shtul-Zhdanovych was contextually analyzed by Serhii Kot (Kot, 2005) and Serhii Stelnykovych (Stelnikovych, 2016). In particular, the researchers focused on functioning of the Kyiv newspaper "Ukrainske Slovo", cooperation of O. Shtul-Zhdanovych with the Resistance Movement of Taras Bulba-Borovets. Thus, a comprehensive study of the activities of O. Shtul-Zhdanovych during World War II was left out of the attention of researchers.

The aim of the article is to study the activities of Oleh ShtulZhdanovych in the occupied Ukrainian territories during World War II.

Findings and discussion. Until 1939 O. Shtul-Zhdanovych was in Warsaw, where he was engaged in social and cultural activities. With the beginning of World War II, he became actively involved in political processes. In fact, the beginning of his political activity is connected with membership in the OUN (M). To a greater extent, the political, social and cultural work of O. Shtul-Zhdanovych was intensified after his acquaintance with O. Olzhych in December, 1939 (ShtulZhdanovych, 1997, p. 6). In the post-war period, Shtul-Zhdanovych wrote many newspaper articles dedicated to O. Olzhych. Of great significance in that case was the article "Strict and Great", which was 
INTERMARUM: history, policy, culture. - Issue 8.

published in the journal "Orlyk", where O. Shtul emphasized O. Olzhych's awareness of the content and consequences of the Nazi policy: "«...». Germany did not show the claws yet ...nor did Gestapo hound its flocks in Europe, and Olzhych had seen the essence of the German barbarians and their failure" (Shtul-Zhdanovych, 1997, p. 86)

During 1939-1941 O. Shtul-Zhdanovych stayed mainly in Krakow and held the position of the OUN (M) Cultural Officer in the General Governorate. Besides, at that time he was engaged in activities related to preparations for the march to the East, while : "«...» coming of the German-Soviet war was an obvious fact for the OUN leadership led by A. Melnyk. "...» The main strategy of the OUN was to use the conditions of war as a chance to restore the state's independence"(Kot, 2005, p. 127).

Major activities were carried out towards formation of the so-called "marching groups", which after the German attack on the USSR were to move deep into the Nazi-occupied territory. There, members of the marching groups were to form local subordinate governing bodies, a semi-legal (and later underground) network etc. It was obvious that the OUN (M) completely fulfilled the task of forming marching groups, because " $" \ldots . . »$ the outbreak of the German-Soviet war in 1941 found the OUN members in a condition of full readiness" (Veryha, 1985, p. 76).

At the time, O. Shtul-Zhdanovych emphasized O. Olzhych's active participation in preparation of the marching groups (Zhdanovych, 1947, p. 61); thus, the OUN (M) entrusted him the leadership of the groups (The OUN Archive in Kyiv. The file "Creators of a New Stage". Sheets 146-147). The marching route in the direction of Kyiv passed through the cities: Lviv - Brody - Rivne - Zhytomyr (Kot, 2005, p. 128). The network of the OUN (M) marching groups, in its turn, was to be established in different places "«...» from Chernihiv to Odessa, the Crimea and Kuban, from Polissya to Kharkiv and Donbass..." (The OUN Archive in Kyiv. The file "Creators of a New Stage". Sheet 149).

O. Shtul-Zhdanovych was appointed to Kyiv marching group, which included leading figures of the OUN (M): Mykola Kapustianskyi, Osyp Boidunyk, Oleh Olzhych, Omelian Senyk, Mykola Stsiborskyi (Shtul-Zhdanovych, 1997, p. 61). The writer and cultural figure Olena Teliha, who had already stayed in Lviv in the second half of July 1941, also went to Ukraine. O. Shtul-Zhdanovych also passed through the city 
IНТЕРМАРУМ: історія, політика, культура. - Вип. 8.

of Lviv as a member of the OUN (M) marching group and noted his impression of what he had seen in the city: "«...» Soviet Lviv made a terrible impression. «...» there were masses of women with young faces and gray hair in the streets..." (Shtul-Zhdanovych, 1997, p. 47). He also paid attention to the policy of Russification and Soviet primitivization, which, in particular, were reflected in the new names of Lviv stores: "«...» when we entered Lviv, the capital of flourishing Western Ukraine, our eyes noticed new signboards and inscriptions made in the Russian language "Ukrpishcheprom", "Indposhiv odezhdy" «...» after that we were not surprised by "Gastronom", although at first we just wanted to howl «...»" (Shtul-Zhdanovych, 1997, p. 46).

By the end of September - the beginning of October 1941, members of the OUN (M) marching group were established in Kyiv. O. Shtul-Zhdanovych wrote about his first impression of Kyiv: "«...» it (Kyiv) lay in front of us like a giant - badly wounded and mutilated, but still formidable with its strength, its anger and its immortality "...»" (Shtul-Zhdanovych, 1997, pp. 54).

In Kyiv, the members of the OUN (M) marching group began to develop the social, political and cultural life not only of the capital, but also of other Ukrainian regions, where the OUN (M) members were established. The living conditions of members of the OUN (M) marching group in Kyiv were far from good. O. Shtul-Zhdanovych together with $\mathrm{O}$. Teliha and her husband Mykhailo lived in a house on Karavaivska Street: "«...» it was a modern house, but in a week or two the supply of heatingwas stopped «...» then the electricity was cut «...» and among other things there was nothing to eat "(Shtul-Zhdanovych, 1997, p. 62).

On October 5, 1941, the Ukrainian National Council was formed in Kyiv on the initiative of the OUN (M). It was to become a body that would take over civil power throughout the German-occupied territory of Ukraine in order to " $" \ldots . . . "$ unite the nation to rebuild the destroyed economy, revive the Ukrainian language and culture..." (Myronets, 2009, pp. 55-56). Mykola Velychkivskyi headed the Ukrainian National Council (Veryha, 1991, p. 70). At the initiative and assistance of the Ukrainian National Council, schools, banks, enterprises, transport, communications, etc. began to function (Zhdanovych, 1947, p. 72). 
INTERMARUM: history, policy, culture. - Issue 8.

An important task of the Ukrainian National Council in Kyiv was to establish the publication of Ukrainian newspapers, the newspaper "Ukrainske Slovo" in particular. The purpose of publication was to promote the ideas of Ukrainian statehood. The first issue of the newspaper was published on September 29, 1941 with circulation of 500 copies. The number of copies was limited "due to the impossibility of establishing an effective printing process" (Kovalchuk, Stelnykovych, 2014, p. 70). This newspaper gained immediate popularity among the population, as evidenced by the memoirs of Yu. Boiko: "«...» in Kyiv there were queues to buy a newspaper «...» individual subscription as impossible, making Kyivans hurry to a newsstand and wait in a queue..." (Boiko, 1955, p. 11).

Some members of the OUN (M) marching group, including O. Shtul-Zhdanovych and O. Teliha, published their articles in the newspaper "Ukrainske Slovo". In particular, O. Shtul-Zhdanovych in his publications highlighted the image of the development of literature in exile, and $\mathrm{O}$. Teliha focused on spiritual issues of the society (Boidunyk, 1967, p. 26). Gradually, the content of the "Ukrainian word" expanded due to the inclusion of appendices "Ostanni Novyny" ("The Latest News") and "Lytavry" ("The Timpani") (Zhdanovych, 1947, p. 78). Notably, the newspaper "Ukrainske Slovo", controlled by members of the OUN (M) and published legally, did not escape German censorship. As a result, overtly pro-German publications appeared in the newspaper from time to time.

By the end of autumn, after establishment of the German civil administration in Kyiv, as well as in the Reichskommissariat "Ukraine", created by the occupiers, there were attacks launched on manifestations of Ukrainian national life that had been intensified in the previous period. Thus, according to the resolution of the Central Leadership of the OUN, it was planned to organize commemoration of the heroes of the Bazar tragedy in the Southern Ukrainian lands. The action took place on November 21, 1941 and was attended by about 10 thousand people (Stelnykovych, 2016, p. 123). Most of them were residents of Zhytomyr Oblast and surrounding areas. One of the first acts against the representatives of the Ukrainian nationalist movement was liquidation of the Ukrainian National Council in Kyiv (Boidunyk, 1967, p. 107). 
IНТЕРМАРУМ: історія, політика, культура. - Вип. 8.

Under these circumstances, functioning of the Kyiv newspaper "Ukrainske Slovo", controlled by the OUN (M), was also banned.

Subsequently, mass arrests of the newspaper's editorial staff were initiated; some of them, including editor-in-chief I. Rohach and O. Teliha, were shot dead by the Nazis in Babyn Yar in early 1942. According to O. Shtul-Zhdanovych, the reason for the arrests and executions of the "Ukrayinske Slovo" employees was that "they spoke the word of truth, they spoke about the right of the Ukrainian people to an independent and dignified life" (To the Thirty Years of Kyiv Victims, 1972, pp. 1). O. Shtul-Zhdanovych highly appreciated the patriotic position of $\mathrm{O}$. Teliha, emphasizing her refusal to flee before her arrest (Shtul-Zhdanovych, 1997, p. 66). O. Shtul-Zhdanovych himself was not arrested by the Nazis only because on February 9, 1942, when the occupiers raided the staff of "Ukrainian Word", he did not arrive in time to the appropriate place (the premises of the Writers' Union) (Shtul-Zhdanovych, 1997, pp. 66).

After the February arrests in 1942, the OUN (M) leadership ordered O. Shtul-Zhdanovych to leave the capital and sent him to Lutsk. He got a job as a teacher of the Ukrainian literature and history in the city gymnasium. Some of O. Shtul-Zhdanovych's fellow party members noted: "Shtul was an extraordinary teacher, and his students admired him" (Paris for Oleh Shtul, 1986, p. 30).

At the same time, during World War II, O. Shtul-Zhdanovych took part in two important conferences of the OUN (M). The first conference took place on May 24-25, 1942 in Pochaiv, and the second one on August 14-15, 1942 in Kyiv (Zek, 2013, p. 25). The latter conference is also called "The Congress of Ukrainian Independists". This name is substantiated by the fact that the congress was attended not only by representatives of the OUN (M), but also by activists of other independent organizations that operated in Dnipro Ukraine. One of the reports at this conference was delivered by O. Shtul-Zhdanovych (Haivas, 1955, p. 281).

Due to financial difficulties, O. Shtul-Zhdanovych soon began to sell newspapers at the news-stand. The main object of sale was the German newspaper "Deutsche-Ukrainische Zeitung", which was published in Lutsk. For the most part, it was bought by German soldiers passing through the city. For Shtul-Zhdanovych the primary task was to 
INTERMARUM: history, policy, culture. - Issue 8.

sell as few newspapers to the Germans as possible to keep them for Ukrainian peasants, who used newspapers as cigarette paper and paid for it with food. Having profit from this venture, O. Shtul once said that at that time it was better to sell a newspaper than to write for it. However, O. Shtul-Zhdanovych did not stay there long, as the OUN (M) leadership appointed him as its representative in the headquarters of T. Bulba-Borovets (Paris for Oleh Shtul, 1986, pp. 82-83).

It should be noted that military and political cooperation between the OUN (M) and T. Bulba-Borovets formations was started on August 5, 1941. Then, for partial consolidation of the national forces of the OUN (M), it concluded an agreement on cooperation with T. BulbaBorovets in the military sphere. Since spring of 1943, O. ShtulZhdanovych worked as a representative of the OUN (M) at the headquarters of the armed formations of T. Bulba-Borovets. At the end of the summer of 1943, he took part in the work of the editorial board of the newspaper "Oborona Ukrainy" ("Protection of Ukraine") of the Ukrainian People's Revolutionary Army of T. Bulba-Borovets. In general, only two issues of the newspaper were published - dated August 1 and August 4, 1943. In the newspaper "Oborona Ukrainy" of August 1, 1943, O. Shtul-Zhdanovych defined the tasks of the Ukrainian People's Revolutionary Army: "We fight for total freedom of the Ukrainian people, which can be perceived only after creating an independent Ukrainian state «...» we fight for the Ukrainian state, where the Ukrainian working class will have an opportunity for a free cultural development «...», where schools of all levels will serve the Ukrainian youth «...» we fight for an independent Ukrainian state "(What We Fight For, 1943, pp. 1-2).

An important area of O. Shtul-Zhdanovych's activity as a member of the Ukrainian People's Revolutionary Army was attempting to communicate with various formations of the Ukrainian independence movement, in particular with the OUN representatives led by Stepan Bandera (OUN (B)) (Bulba-Borovets, 1981, p. 257). Therefore, on May 20, 1943, O. Shtul-Zhdanovych took part in a meeting, aiming at consolidation of the forces of three partisan formations: the OUN (M), the OUN (B) and the divisions of T. Bulba-Borovets. Due to various circumstances, representatives of the OUN (B) did not attend the meeting. O. Zhdanovych noted in his memoirs: " $<\ldots$. Taras Bulba came 
IНТЕРМАРУМ: історія, політика, культура. - Вип. 8.

from the Ukrainian Insurgent Army, Zhdanovych - from the OUN, no one from the Banderites «...»..." (Zhdanovych, 1948, pp. 22). Three months later, T. Bulba-Borovets appealed to the OUN (B) again on the issue of creating a united revolutionary front, but the attempt did not have a positive result. On August 18, 1943, T. Bulba-Borovets arrived at a hamlet near Khmelivka in the Kostopil region, where he was to meet with the Ludwypil Hundred. However, on the night of August 18-19, 1943, the Ludwypil Hundred was surrounded and defeated by the OUN (B) forces. Sotnyk Shtul-Zhdanovych was also there (Zhdanovich, 1948, p. 30).

During the analyzed period, O. Shtul-Zhdanovych's younger brother Vasyl also carried out active political activity. Maksym Skorupskyi, an activist of the Ukrainian underground, left in his memoirs an interesting description of both brothers, who "were not similar in appearance or character. Vasyl was a brunette with brown eyes. Oleh had blond hair and deep gray eyes" (Paris for Oleh Shtul, 1986, pp. 146-147).

As the Soviet troops approached the territory of the Ukrainian People's Revolutionary Army (mainly Rivne and Volyn Oblasts), in November 1943 T. Bulba-Borovets decided to initiate negotiations with some German authorities (the USSR was the main enemy of the movement throughout World War II, while Germany was treated as a temporary occupier). The purpose of the negotiations was to agree on transfer of weapons by retreating German troops to the forces of $\mathrm{T}$. Bulba-Borovets. Due to the retreat of the German army, a special headquarters was established at the Abwehr division "East". T. BulbaBorovets began negotiations with the headquarters, and O. ShtulZhdanovych joined him. On November 17, 1943, T. Bulba-Borovets and O. Shtul-Zhdanovych started negotiations with the Germans in Rivne. However, they were later taken to Warsaw and then to Berlin and imprisoned in the Sachsenhausen concentration camp. In December 1943, O. Shtul-Zhdanovych stayed in solitary confinement. About this period of his life he noted: "every morning a stench from the nearby crematorium burst through the window open for ventilation $\langle\ldots\rangle$, and every evening the whole bunker trembled from the bombs falling on Berlin" (Shtul-Zhdanovych, 1997, p. 575). 
INTERMARUM: history, policy, culture. - Issue 8.

Later, O. Shtul-Zhdanovych was transferred to the cell of T. BulbaBorovets (Shtul-Zhdanovych, 1997, p. 575). O. Shtul-Zhdanovych and Otaman Bulba-Borovets were released from prison in the second half of 1944 due to formation of the Ukrainian National Committee. In fact, from the end of 1944, the emigration period of O. Shtul-Zhdanovych's life and activity began.

Conclusions. During World War II, the political, social and cultural activities of $\mathrm{O}$. Shtul-Zhdanovych were actively manifested. It was primarily due to his membership in the Organization of Ukrainian Nationalists under the leadership of Andrii Melnyk. At the initial stage, O. Shtul-Zhdanovych, as a member of the OUN (M), acted as a Cultural Officer. These activities, in particular, included the preparation of publications on Ukrainian issues for legal Ukrainian-language publications. O. Shtul-Zhdanovych, as a member of the OUN (M) marching group, took active part in the development of the social and political life of occupied Kyiv. He was a supporter of the idea of uniting various Ukrainian political and military forces. The corresponding activity was implemented in practice with his stay at the headquarters of the armed formations of T. Bulba-Borovets. At the end of 1943, O. Shtul-Zhdanovych was imprisoned by the Germans in the Sachsenhausen concentration camp. After his release in late 1944, the emigration period of his life began.

It should be noted that O. Shtul-Zhdanovych's activity during World War II has prospects for further research. The participation of O. Shtul-Zhdanovych and T. Bulba-Borovets in negotiations with the Germans at the final stage of World War II has a significant potential for study. Of great importance is studying the conditions of O. ShtulZhdanovych's and other Ukrainian political prisoners' stay in the Nazi Sachsenhausen concentration camp.

Gratitude. I would like to thank the members of the editorial board of the journal and the reviewers for their constructive remarks, wishes and consultations provided during the preparation of the article for publication.

Financing. The author did not receive financial support for research and publication of this article. 
IНТЕРМАРУМ: історія, політика, культура. - Вип. 8.

\section{References}

The OUN Archive in Kyiv. The file "Creators of a New Stage". 1511.

Boidunyk, O. (1967). Na perelomi [At the Break]. Paryzh, 153 p. [in Ukrainian].

Boiko, Yu. (1955). U siaivi nashoho Kyieva [In the Light of our Kyiv]. Vinnipeh, 224 p. [in Ukrainian].

Bulba-Borovets, T. (1981). Armiia bez derzhavy. Slava i trahediia ukrainskoho povstanskoho rukhu [Army Without a State. The Glory and Tragedy of the Ukrainian Rebel Movement]. Vinnipeh, 327 p. [in Ukrainian].

Veryha, V. (1985). Na zov Kyieva [To the Call of Kyiv]. Toronto - NiuYork, 559 p. [in Ukrainian].

Veryha, V. (1991). Vtraty OUN v chasy Druhoii Svitovoii Viiny [The Losses in the Times of the World War II]. Toronto, 206 p. [in Ukrainian].

Haivas, Ya. (1955). Perelomovyi rik. Orhanizatsiia Ukrainskykh Natsionalistiv. 1929-1954 [A Breaking Year. The Organization of Ukrainian Nationalists. 1929-1954]. Paryzh, 291 p. [in Ukrainian].

Zhdanovych, O. (1947). Na zov Kyieva [To the Call of Kyiv]. Vinnipeh, 83 p. [in Ukrainian].

Zhdanovych, O. (1948). V imiia pravdy [In the Name of the Truth]. Buenos-Aires, 40 p. [in Ukrainian].

Za scho my boremosia [What We Fight For]. (1943). Oborona Ukrainy, August, 1, 1-2. [in Ukrainian].

Zek, B. (2013). Oleh Shtul u borotbi za Ukrainu [Oleh Shtul in the Fight for Ukraine], 110. [in Ukrainian].

Kovalchuk, I., Stelnykovych, S. (2014). Narys diialnosti OUN pid provodom A. Melnyka na Zhytomyrshchyni u druhii polovyni $1941 \mathrm{r}$. [Outlines of the Activity of the OUN under the Direction of A. Melnyk in Zhytomyr Oblast in the Second Half of 1941]. Zhytomyr, 188 p. [in Ukrainian].

Kot, S. (2005). Pidpillia OUN v okupovanomu Kyievi. 1941-1943. Druha svitova viina i dolia narodiv Ukrainy [The OUN Underground in Occupied Kyiv. 1941-1943. World War II and the Fate of the Peoples of Ukraine]. Materialy Vseukrainskoi naukovoi konferentsii, 126-140. [in Ukrainian].

Myronets, N. (2009). Olena Teliha. Kyiv, 64 p. [in Ukrainian].

Paryzh dlia Oleha Shtulia [Paris for Oleh Shtul]. (1986). Paryzh, 359 p. [in Ukrainian].

Stelnykovych, S. (2016). Bazarska trahediia 21 lystopada 1921 r. v istorychnii pamiati ukrainskoho narodu [The Bazar Tragedy of November 21, 1921 in the Historical Memory of the Ukrainian People]. Materialy IV Vseukrainskoi naukovoi konferentsii "Problemy doslidzhennia krainskoho vyzvolnoho rukhu XX stolittia (do 75-richia Poliskoi Sichi ta 95-richia Druhoho zymovoho pohodu)", 121-125. [in Ukrainian].

98 


\section{INTERMARUM: history, policy, culture. - Issue 8. ISSN 2518-7694 (Print) ISSN 2518-7708 (Online)}

U trydtsiatylittia kyivskykh zhertv [To the Thirty Years of Kyiv Victims]. (1972). Ukrainske slovo, February 13, 1. [in Ukrainian].

Shtul-Zhdanovych, O. (1997). Tsinoiu krovy [At the Price of Blood]. Kyiv, 592 p. [in Ukrainian].

\section{Степанчук ОЛЬга. ДІЯЛЬНІСТЬ ОЛЕГА ШТУЛЯ-ЖДАНОВИЧА ПІД ЧАС ДРУГОЇ СВІТОВОЇ ВІЙНИ}

\section{Анотація}

Мета статті полягає у дослідженні політичної, громадської, культурницької діяльності Олега Штуля-Ждановича під час Другої світової війни. У процесі написання роботи використано загальнонаукові $i$ спеціальні історичні методи дослідження, основні принципи історичного пізнання. Методологія. Принципи історизму і науковості дозволили відтворити діяльність Олега Штуля-Ждановича у взасмозв'язку з тогочасними суспільно-політичними подіями. Принцип об'єктивності допоміг критично проаналізувати літературноджерельну базу дослідження. Принциип системності дозволив сформувати иілісну картину діяльності Олега Штуля-Ждановича у роки Другої світової війни. Наукова новизна дослідження полягає в тому, що тут уперше на основі наявної джерельної бази подано узагальнюючу картину діяльності Олега Штуля-Ждановича в роки Другої світової війни. У результаті автор приходить до висновків, що політична діяльність Олега Штуля-Ждановича у роки Другої світової війни була досить активною та різносторонньою. Він став учасником Похідних Груп ОУН(М) та брав активну участь у політичному житті окупованого Києва, тісно співпращював з провідними діячами начіоналістичного руху, передусім з Оленою Телігою та Олегом Ольжичем. Громадсько-культурна діяльність Олега Штуля-Ждановича у роки Другої світової війни представлена його роботою у редакиї газети «Українське слово» (Київ). Вагоме значення мала співпрачя Олега Штуля-Ждановича з Тарасом Бульбою-Боровием, оскільки мета співпраџі полягала в об'єднанні усіх самостійницьких сил перед спільним ворогом. По суті, саме завдяки їхній співпраиі можна говорити про постійний політичний зв'язок між ОУН(М) та силами Тараса Бульби-Боровия. Згідно поглядів Олега ШтуляЖдановича, головна ціль будь-якої боротьби полягала у здобутті незалежності Украӥни. Загалом, у дослідженні надано оиінку політичній, громадській, культурницькій діяльності Олега Штуля-Ждановича на українських землях під час Другої світової війни.

Ключові слова: Олег Штуль-Жданович, Друга світова війна, ОУН(М), газета «Українське слово» (Київ), політична діяльність 
IНТЕРМАРУМ: історія, політика, культура. - Вип. 8. ISSN 2518-7694 (Print) ISSN 2518-7708 (Online)

\section{Stepanczuk Olga. DZIALALNOŚĆ OLEGA SZTUL-ŻDANOWICZA PODCZAS II WOJNY ŚWIATOWEJ}

\section{Streszczenie}

Cel artykułu polega na tym, żeby zbadać polityczna, spoleczna $i$ kulturalna działalność Olega Sztul-Żdanowicza w czasie II wojny światowej. $W$ trakcie napisania pracy wykorzystano ogólne $i$ szczególne metody badań historycznych, podstawowe zasady poznania historycznego. Zasady historyzmu i naukowości pozwolity odtworzyć działalność Olega Sztul-Żdanowicza w związu z ówczesnymi wydarzeniami społeczno-politycznymi. Zasada obiektywności pomogła w krytycznej analizie literatury i bazy źródtowej tego badania. Zasada systematyczności pozwoliła na ukształtowanie catościowego obrazu działalności Olega Sztul-Żdanowicza podczas II wojny światowej. Oryginalnościa naukowa badania jest to, że po raz pierwszy na podstawie dostęnej bazy źródłowej przedstawiono uogólniony obraz działalności Olega Sztul-Żdanowicza w czasie II wojny światowej. W wyniku autor stwierdza, że działalność polityczna Olega Sztul-Żdanowicza podczas II wojny światowej była dość aktywna i różnokierunkowa. Został członkiem Pochodnych Grup OUN (M) i aktywnie brat udziat $w$ życiu politycznym okupowanego Kijowa, ściśle wspótpracując z wybitnymy postaciami ruchu nacjonalistycznego, przede wszyskim z Olena Teliga $i$ Olegiem Olżyczem. Działalność społeczna $i$ kulturalna Olega Sztul-Żdanowicza podczas II wojny światowej reprezentuje jego praca w redakcji gazety „Ukraińskie Stowo” (Kijów). Ogromne znaczenie miała jego wspótpraca z Tarasem Bulba-Borowcem, ponieważ jej celem byto zjednoczenie wszystkich niezależnych sit przed wspólnym wrogiem. Tak naprawdę dzięki ich wspótpracy możemy mówić o trwałym związu politycznym między OUN (M) a siłami Tarasa Bulby-Borowca. Wedtug Olega SztulŻdanowicza głównym celem każdej walki było odzyskanie przez Ukraine niepodległości. Ogólnie mówiac, $w$ pracy dokonano oceny politycznej, społecznej $i$ kulturalnej działalności Olega Sztul-Żdanowicza na ziemiach ukraińskich w okresie II wojny światowej.

Stowa kluczowe: Oleg Sztul-Żdanowicz, II wojna światowa, OUN (M), gazeta „Ukraińskie Stowo” (Kijów), działalność polityczna.

The article was received 05.20.2020 Article recommended for publishing 09.17.2020 